\title{
Reduction in massive postpartum haemorrhage and red blood cell transfusion during a national quality improvement project, Obstetric Bleeding Strategy for Wales, OBS Cymru: an observational study
}

Sarah F. Bell ${ }^{1 \dagger}$, Rachel E. Collis ${ }^{1 \dagger}$, Philip Pallmann², Christopher Bailey ${ }^{3}$, Kathryn James ${ }^{1}$, Miriam John ${ }^{4}$, Kevin Kelly ${ }^{3}$, Thomas Kitchen ${ }^{1}$, Cerys Scarr ${ }^{5}$, Adam Watkins ${ }^{6}$, Tracey Edey ${ }^{7}$, Elinore Macgillivray ${ }^{6}$, Kathryn Greaves ${ }^{8}$, Ingrid Volikas ${ }^{3}$, James Tozer $^{9}$, Niladri Sengupta ${ }^{10}$, Iolo Roberts ${ }^{3}$, Claire Francis ${ }^{5}$ and Peter W. Collins ${ }^{11^{*}}$ (i)

\footnotetext{
Abstract

Background: Postpartum haemorrhage (PPH) is a major cause of maternal morbidity and mortality and its incidence is increasing in many countries despite management guidelines. A national quality improvement programme called the Obstetric Bleeding Strategy for Wales (OBS Cymru) was introduced in all obstetric units in Wales. The aim was to reduce moderate PPH $(1000 \mathrm{~mL})$ progressing to massive PPH $(\geq 2500 \mathrm{~mL})$ and the need for red cell transfusion.

Methods: A PPH care bundle was introduced into all 12 obstetric units in Wales included all women giving birth in 2017 and 2018 ( $n=61,094)$. The care bundle prompted: universal risk assessment, quantitative measurement of blood loss after all deliveries (as opposed to visual estimation), structured escalation to senior clinicians and point-of-care viscoelastometric-guided early fibrinogen replacement. Data were submitted by each obstetric unit to a national database. Outcome measures were incidence of massive PPH $(\geq 2500 \mathrm{~mL})$ and red cell transfusion. Analysis was performed using linear regression of the all Wales monthly data.
}

\footnotetext{
* Correspondence: Peter.collins@wales.nhs.uk

†Sarah F Bell and Rachel E Collis are joint first authors and contributed equally to the project and manuscript.

${ }^{11}$ Institute of Infection and Immunity, School of Medicine, Cardiff University, Cardiff, UK

Full list of author information is available at the end of the article
}

(c) The Author(s). 2021 Open Access This article is licensed under a Creative Commons Attribution 4.0 International License, which permits use, sharing, adaptation, distribution and reproduction in any medium or format, as long as you give appropriate credit to the original author(s) and the source, provide a link to the Creative Commons licence, and indicate if changes were made. The images or other third party material in this article are included in the article's Creative Commons licence, unless indicated otherwise in a credit line to the material. If material is not included in the article's Creative Commons licence and your intended use is not permitted by statutory regulation or exceeds the permitted use, you will need to obtain permission directly from the copyright holder. To view a copy of this licence, visit http://creativecommons.org/licenses/by/4.0/ The Creative Commons Public Domain Dedication waiver (http://creativecommons.org/publicdomain/zero/1.0/) applies to the data made available in this article, unless otherwise stated in a credit line to the data. 
Results: Uptake of the intervention was good: quantitative blood loss measurement and risk assessment increased to 98.1 and $64.5 \%$ of all PPH $\geq 1000 \mathrm{~mL}$, whilst ROTEM use for PPH $\geq 1500 \mathrm{~mL}$ increased to $68.2 \%$. Massive PPH decreased by 1.10 ( $95 \% \mathrm{Cl} 0.28$ to 1.92$)$ per 1000 maternities per year $(P=0.011)$. Fewer women progressed from moderate to massive PPH in the last 6 months, 74/1490 (5.0\%), than in the first 6 months, $97 / 1386(7.0 \%),(P=0.021)$. Units of red cells transfused decreased by 7.4 ( $95 \% \mathrm{Cl} 1.6$ to 13.2) per 1000 maternities per year $(P=0.015)$. Red cells were transfused to $350 / 15204(2.3 \%)$ and $268 / 15150(1.8 \%)(P=0.001)$ in the first and last 6 months, respectively. There was no increase in the number of women with lowest haemoglobin below $80 \mathrm{~g} / \mathrm{L}$ during this time period. Infusions of fresh frozen plasma fell and there was no increase in the number of women with haemostatic impairment.

Conclusions: The OBS Cymru care bundle was feasible to implement and associated with progressive, clinically significant improvements in outcomes for PPH across Wales. It is applicable across obstetric units of widely varying size, complexity and staff mixes.

Keywords: Postpartum haemorrhage, Quality improvement, Coagulopathy, Blood transfusion, Viscoelastometry

\section{Background}

Bleeding after childbirth (postpartum haemorrhage, $\mathrm{PPH}$ ) is the leading cause of maternal death worldwide [1]. In resource rich countries $\mathrm{PPH}$ causes $80 \%$ of severe maternal morbidity and its incidence is increasing in many regions [2, 3], including Wales [4], despite international guidance [5-7]. In the UK PPH is described as moderate at $1000 \mathrm{~mL}$ blood loss and severe at $2000 \mathrm{~mL}$ [6]. Massive $\mathrm{PPH}$ is defined as $\geq$ $2500 \mathrm{~mL}$ and, in resource rich countries, is associated with a hysterectomy rate of $6 \%$ and intensive care admission in $11.8 \%$ of cases [3]. Post-traumatic stress disorder is common after PPH [8]. Multi-professional management of PPH requires the skills of midwives, obstetricians, anaesthetists, healthcare support staff and haematologists working in an effective team. Variations in care are widely reported, with delays in escalation to senior staff a common theme $[9,10]$. A recent confidential enquiry identified deficiencies in care, compared to guidelines, in $90 \%$ of cases [11].

Postpartum haemorrhage may be exacerbated by haemostatic impairment. A Clauss fibrinogen below $2 \mathrm{~g} / \mathrm{L}$ is associated with progression of bleeding [12, 13], although clinically significant deficiencies of other clotting factors and platelets are less common [14-16]. In severe $\mathrm{PPH}$, laboratory coagulation results are often too slow to be useful clinically and guidelines recommend the use of empirical treatment with fixed ratios of red blood cells (RBC), fresh frozen plasma (FFP) and platelets, based on data derived from major trauma $[5,6]$. This results in many women receiving blood components when haemostasis is normal [17]. Point-of-care haemostasis test results, using viscoelastometry, are available within $10 \mathrm{~min}$ and can direct timely and targeted replacement of fibrinogen and avoid unnecessary FFP during PPH [15, 18-20].

International PPH quality improvement projects have been undertaken with the aim of standardising care and improving outcomes. Interventions have included risk assessment, quantitative measurement of blood loss and escalation to senior clinicians, although to date all have used empirical, fixed-ratio transfusion therapy [21-24]. OBS Cymru is a national quality improvement project developed by combining lessons learnt during 10 -years of research [17] with themes emerging from international PPH quality improvement projects [21-24]. OBS Cymru introduced an integrated care bundle into all obstetric units in Wales [25]. A key and unique feature was the inclusion of viscoelastometric point-of-care haemostatic tests to guide targeted blood component administration $[15,18-20]$. We report the impact of OBS Cymru over a 2-year period.

\section{Methods}

\section{Intervention}

Launched in November 2016, OBS Cymru introduced a PPH care bundle between January and April 2017 into all 12 obstetric units in Wales. These obstetric units support between 500 and 6000 births per year, with about 31,000 births across Wales. The lead research and development office designated OBS Cymru as a quality improvement project and service evaluation according to NHS guidance. Consequently ethical approval and individual consent to collect and report data was not required.

The design, initiation and project interventions have been described in detail previously [25]. OBS Cymru funding provided a Rotem Sigma ${ }^{\circ}$ point-of-care coagulation device (Instrumentation Laboratories, Werfen, Barcelona, Spain) for use in each obstetric unit. The intervention promoted:

1. Risk assessment of all mothers admitted to delivery suite. The risk assessment tool is available [26].

2. Quantitative measurement of blood loss from delivery using volumetric and gravimetric techniques for all births as opposed to visual 
estimation. Details of the method and validation data supporting quantitative measurement have been published $[4,25,27]$.

3. Escalation of care to senior clinicians, if not already involved, at specified volumes of blood loss. An obstetrician, senior midwife and anaesthetist were required to attend the mother at $1000 \mathrm{~mL}$, at the latest, and a consultant obstetrician and anaesthetist informed at $1500 \mathrm{~mL}$

4. Point-of-care tests of haemostasis were taken at $1000 \mathrm{~mL}$ or earlier for clinical concern. If required, targeted, early replacement of fibrinogen was administered following a published algorithm [26]. Tranexamic acid was infused as soon as abnormal bleeding was recognised and repeated if bleeding continued [28].

The intervention was intended for all births and was not limited to those complicated by abnormal bleeding. It was underpinned by a standardised paperwork proforma that prompted management and created a contemporaneous record of findings and actions [26]. An all Wales guideline reinforced the intervention and standardised obstetric management including uterotonic use [29]. Antenatal anaemia, cell salvage and transfusion policies were unchanged throughout the project.

The Rotem point-of-care coagulation devices were supported by a validated algorithm $[15,17,18,26]$ and were compliant with internal and external quality assurance. A minor revision of the Rotem interpretation algorithm was introduced in 2018 to emphasise the importance of correcting hypofibrinogenaemia before considering FFP [26]. Haemostatic impairment was defined as fibrinogen $<2 \mathrm{~g} / \mathrm{L}$, Fibtem A $<12 \mathrm{~mm}$ or PT or aPTT $>1.5$ times normal $[6,30]$ (equating to PT $>16$ or aPTT > 50 s). In autumn 2018 all Rotem devices received a hardware update which was associated with slightly lower Fibtem A5 measurements, the blood product algorthim was not adjusted.

The national team co-ordinated multi-professional training at each unit, as described [25], this training was front-loaded at the start of the project with top-up training throughout the 2 year period. A lead midwife, obstetrician, anaesthetist and haematologist were appointed at each site to support ongoing training and oversee the project locally with the midwifery time funded by the project. The intervention was introduced during the first 6 month period (January to June 2017) and integrated into standard care obstetric units throughout 2017 and 2018. Training covered quantitative measurement of blood loss, escalation of care and interpretation of Rotem results. The OBS Cymru principles were integrated into PROMPT (PRactical Obstetric Multi-Professional Training) for Wales to support sustainability [31]. Annual multi- professional national meetings allowed dissemination of learning and sharing of good practice.

\section{Data sources}

The Welsh Maternity Indicators Dataset (NHS Wales Informatics Service) provided data regarding number of births and mode of delivery. An all Wales OBS Cymru database was established by Improvement Cymru. Women experiencing bleeds $\geq 1000 \mathrm{~mL}$ or in whom there was concern about abnormal bleeding had a limited dataset collected. Women with bleeds $\geq 1500 \mathrm{~mL}$ or who received a transfusion had more detailed information collected (supplementary Figure 1).

In addition, five audits were undertaken to establish the uptake of measured blood loss and use of the paperwork proforma and the risk assessment tool. Audits included up to 30 consecutive women from each obstetric unit, irrespective of blood loss. Individual units were encouraged to advertise the audit and allow the midwife caring for the patient to contribute data following delivery. Audit data was provided by all 12 obstetric units in October 2016 ( $n=510$, before OBS Cymru started), June $2017(n=455)$ and June $2018(n=492)$, from 11 units in December $2017(n=405)$, and from 7 units in December $2018(n=259)$.

Anonymous patient surveys were performed in 2017 (June-December) and 2018 (September). Local teams circulated forms to women experiencing PPH $\geq 1000 \mathrm{~mL}$. Questions explored communication with the mother and her family and areas for improvement in care. A staff questionnaire was circulated to local leadership teams between September and December 2018 to aid understanding of how OBS Cymru had changed local practice.

\section{Analysis}

Data are summarised descriptively with continuous variables reported as median, inter-quartile range (IQR) and range and categorical variables as number and percent or per 1000 maternities. Descriptive data were reported in four 6-month periods between January 2017 and December 2018 to show changes across time. The intervention was being implemented during January to June 2017 and this time period is compared to the last 6 month period, after the intervention had been adopted, in some analyses. This comparison was chosen to reflect project uptake and prior to any analyses being performed. In addition, an interrupted time series analysis was performed to investigate the trend of bleeds $\geq 2500$ $\mathrm{mL}$ before and after the intervention was introduced.

Changes in the proportion of women experiencing massive $\mathrm{PPH}$, the number of units of $\mathrm{RBC}$ transfused and intensive care admission were analysed by linear regression using the all Wales monthly data. A simple 
linear relationship was found to be the best model, with higher-order terms not leading to any substantial improvements in the model. The dependent variables were $\mathrm{PPH} \geq 2500 \mathrm{~mL}$, units of RBC transfused in Wales and episodes of intensive care and the independent variable was months in each case. Estimates are reported with 95\% confidence intervals (CI). Sensitivity analyses using quasi-Poisson regression models with total maternities as offset provided very similar results. Chi square test was used to compare events in the first and last 6 month periods. Audit results are presented as the percentage of cases where individual interventions were performed with box plots illustrating completion of all components. Funnel plots were used to indicate variations between units. Data were analysed using SPSS version 23 , R version 3.6.0 and ggplot2 version 3.2.0.

\section{Results}

\section{Demographics}

Between 1st January 2017 and 31st December 2018, 61, 094 women gave birth in Wales. Mode of delivery was unassisted vaginal for $62.6 \%$, instrumental vaginal 9.5\%, emergency caesarean section $14.4 \%$ and non-emergency caesarean section $13.5 \%$. There were 6024 episodes (98.6/1000 maternities) recorded on the OBS Cymru database because of PPH $\geq 1000 \mathrm{~mL}$ or clinical concern of abnormal bleeding. The number of episodes increased during the project, possibly because of better recognition of total blood loss as quantitative measurement replaced visual estimation (Table 1). For PPH $\geq 1500 \mathrm{~mL}, 2209$ episodes (36.2/1000 maternities) were reported. The mode of delivery, causes of bleeding and first recorded haemoglobin $(\mathrm{Hb})$ and Clauss fibrinogen remained constant throughout (Table 1).

\section{Uptake of OBS Cymru intervention}

Uptake increased for all components of the OBS Cymru intervention at all sites. Uptake increased progressively across the 2 year period (Table 1 and Fig. 1). Quantitative blood loss measurement increased from 83 to $98 \%$ for PPH $\geq 1000 \mathrm{~mL}$ and Rotem analysis increased from 38 to $68 \%$ of episodes with $\geq 1500 \mathrm{~mL}$ blood loss. The proportion of women receiving treatment that was compliant with the blood component algorithm increased from 19 to $68 \%$ (Table 1). Audit data of consecutive women, irrespective of blood loss volume, showed the variation between sites in the percentage of maternities where blood loss was measured, risk assessment performed and standardised paperwork used (Fig. 1).

\section{Severity of postpartum haemorrhage} Incidence of massive postpartum haemorrhage

Massive PPH (blood loss $>2500 \mathrm{~mL}$ ) fell from 6.4 to 4.9 / 1000 maternities between the first and last 6 month periods (Table 2). Regression analysis suggested a progressive fall across the 24 month period with an estimated decrease in massive PPH of 1.10 (95\% CI 0.28 to 1.92)/1000 maternities/year $(P=0.011)$ (Fig. 2a). The incidence of massive PPH at each obstetric unit during the first and last 6 months is shown in Fig. $2 b$ and c. These illustrate the overall decrease in massive PPH in Wales and a reduction in the number of obstetric units with massive haemorrhage rates above 10/1000 maternities. More detailed obstetric unit level data are shown in supplementary material Table 1 . Information about the incidence of massive PPH in Wales before and after OBS Cymru is shown as an interrupted time series analysis in supplementary Figure 2 demonstrating a statistically significant change in the trend of massive haemorrhage.

The all Wales incidence of PPH $\geq 1000 \mathrm{~mL}$ increased, $\mathrm{PPH} \geq 1500 \mathrm{~mL}$ remained stable and $\geq 2000 \mathrm{~mL}$ fell slightly (Table 2) throughout the 2 year period. The ratio of moderate PPH $(1000 \mathrm{~mL})$ vs massive PPH $(\geq 2500$ $\mathrm{mL}$ ) fell throughout the 2 year period; in the first 6 months, 97/1386 (7.0\%), second 6 months $92 / 1480$ (6.2\%), third 6 months $76 / 1412(5.3 \%)$ and last 6 months, $74 / 1490(5.0 \%) \quad(P=0.021$ comparing first and last 6 months).

\section{Intensive care admission, hysterectomy and length of hospital stay}

The estimated decrease in intensive care admission was 0.31 (95\% CI: - 0.21-0.84)/1000 maternities/year $(P=$ $0.23)$. The total time spent in intensive care fell but this was due mainly to a prolonged stay of $168 \mathrm{~h}$ for one woman in the first 6 months (Table 2). There were 22 hysterectomies in total $(0.36 / 1000$ maternities $)$, of which 19 were associated with PPH (0.31/1000) (Table 2). Of these hysterectomies, $11 / 19$ (58\%) were for placenta accreta, increta or praevia and are likely to represent appropriate care $[6,7]$ The eight hysterectomies for $\mathrm{PPH}$ that were unrelated to abnormal placentation occurred at $0.13,0.06,0.27$ and $0.07 / 1000$ maternities in each 6 month period. These numbers are too small for meaningful comparison. The length of hospital stay for women with $\mathrm{PPH} \geq 1500 \mathrm{~mL}$ was similar throughout (Table 2).

\section{Transfusion of red blood cells and blood components}

The proportion of women transfused RBCs for PPH fell from $350 / 15204(2.3 \%)$ to $268 / 15150(1.8 \%)$ between the first and last 6 month periods, $(P=0.0010)$. The total number of units of RBCs transfused in Wales fell from 54.1 to $40.2 / 1000$ (Table 3). Regression analysis estimated that the number of units of RBCs transfused for PPH fell by 7.4 (95\% CI 1.6-13.2)/1000 maternities/year, $P=0.015$ (Fig. 3a and Table 3). The total number of units of $\mathrm{RBC} / 1000$ maternities transfused at each 
Table 1 Demographics of women experiencing postpartum haemorrhage in Wales and uptake of the OBS Cymru intervention

\begin{tabular}{|c|c|c|c|c|}
\hline & $\begin{array}{l}\text { Jan-Jun } \\
2017\end{array}$ & Jul-Dec 2017 & $\begin{array}{l}\text { Jan-Jun } \\
2018\end{array}$ & Jul-Dec 2018 \\
\hline Total number of maternities in Wales & 15,204 & 15,986 & 14,754 & 15,150 \\
\hline $\begin{array}{l}\text { Episodes with } \geq 1000 \mathrm{~mL} \text { blood loss or clinical concern of abnormal bleeding } \mathrm{N} \text { (/1000 } \\
\text { maternities) }\end{array}$ & $1448(95.2)$ & $1519(95.1)$ & $1499(101.6)$ & $1558(102.8)$ \\
\hline Episodes with $\geq 1500 \mathrm{~mL}$ blood loss $\mathrm{N}$ (/1000 maternities) & $547(36.0)$ & $588(36.8)$ & $530(35.9)$ & $544(35.9)$ \\
\hline \multicolumn{5}{|l|}{ Mode of delivery } \\
\hline Unassisted vaginal: n (\%) & $211(38.6)$ & $228(38.8)$ & $203(38.3)$ & $184(33.8)$ \\
\hline Instrumental vaginal: n (\%) & $115(21.0)$ & $116(19.7)$ & $123(23.2)$ & $147(27.0)$ \\
\hline Non-emergency caesarean section: $\mathrm{n}(\%)$ & $181(33.1)$ & $194(33.0)$ & $170(32.1)$ & $161(29.6)$ \\
\hline Emergency caesarean section: $\mathrm{n}(\%)$ & $40(7.3)$ & $50(8.5)$ & $34(6.4)$ & $51(9.4)$ \\
\hline Not recorded: n (\%) & $0(0)$ & $0(0)$ & $0(0)$ & $1(0.2)$ \\
\hline \multicolumn{5}{|c|}{ Cause of bleeding for episodes with $\geq 1500 \mathrm{~mL}$ blood loss N (\%) (NB many bleeds had multiple causes) } \\
\hline Uterine atony & $323(59.0)$ & $352(59.9)$ & $276(52.1)$ & $315(57.9)$ \\
\hline Surgery related & $142(26.0)$ & $142(24.1)$ & $135(25.5)$ & $161(29.6)$ \\
\hline Genital tract trauma & $175(32.0)$ & $185(31.5)$ & $178(33.6)$ & $189(34.7)$ \\
\hline Extragenital bleeding only & $6(1.1)$ & $1(0.2)$ & $12(2.3)$ & $5(0.9)$ \\
\hline Uterine rupture & $4(0.7)$ & $4(0.7)$ & $1(0.2)$ & $0(0.0)$ \\
\hline Placenta praevia & $16(2.9)$ & $8(1.4)$ & $15(2.8)$ & $10(1.8)$ \\
\hline Placenta accrete & $5(0.9)$ & $7(1.2)$ & $5(0.9)$ & $5(0.9)$ \\
\hline Amniotic fluid embolus & $0(0.0)$ & $1(0.2)$ & $0(0.0)$ & $0(0.0)$ \\
\hline Uterine inversion & $1(0.2)$ & $1(0.2)$ & $0(0.0)$ & $1(0.2)$ \\
\hline Placental abruption & $17(3.1)$ & $14(2.4)$ & $17(3.2)$ & $23(4.2)$ \\
\hline Retained products & $63(11.5)$ & $46(7.8)$ & $57(10.8)$ & $45(8.3)$ \\
\hline No cause reported & $1(0.2)$ & $0(0.0)$ & $1(0.2)$ & $0(0.0)$ \\
\hline \multicolumn{5}{|l|}{ First blood test after recognition of haemorrhage for $\mathrm{PPH} \geq 1500 \mathrm{~mL}$} \\
\hline Haemoglobin g/L: Med (IQR), range & $\begin{array}{l}104(93-114) \\
62-156\end{array}$ & $\begin{array}{l}104(94-115) \\
57-164\end{array}$ & $\begin{array}{l}103(93-115) \\
60-146\end{array}$ & $\begin{array}{l}102(92-113) \\
52-144\end{array}$ \\
\hline Clauss fibrinogen g/L: Med (IQR) & $\begin{array}{l}4.2(3.6-5) \\
0.3-7.9\end{array}$ & $\begin{array}{l}4.2(3.6-4.9) \\
0.6-7.4\end{array}$ & $\begin{array}{l}4.3(3.7-4.9) \\
0.3-8.3\end{array}$ & $\begin{array}{l}4.3(3.7-4.9) \\
0.4-9.8\end{array}$ \\
\hline \multicolumn{5}{|l|}{ Uptake of OBS Cymru intervention } \\
\hline Risk assessment completed. All Wales: $\mathrm{n}(\% \text { of all episodes } \geq 1000 \mathrm{~mL})^{a}$ & $23(1.6)$ & $399(26.2)$ & $931(62.1)$ & $1003(64.4)$ \\
\hline Percent completion in individual units: Med (IQR) range ${ }^{a}$ & $\begin{array}{l}0.8(0-1.7) \\
0-3.3\end{array}$ & $\begin{array}{l}25(22-40) \\
16-59\end{array}$ & $\begin{array}{l}82(74-90) \\
36-96\end{array}$ & $\begin{array}{l}88(68-97) \\
37-99\end{array}$ \\
\hline Paperwork completed. All Wales: $n$ (\% of all episodes $\geq 1000 \mathrm{~mL}$ ) ${ }^{\text {a }}$ & 28/1166 (2.4) & $\begin{array}{l}503 / 1274 \\
(39.5)\end{array}$ & $\begin{array}{l}724 / 1210 \\
(59.8)\end{array}$ & $\begin{array}{l}802 / 1262 \\
(63.5)\end{array}$ \\
\hline Percent completion in individual units: Med (IQR), range ${ }^{a}$ & $\begin{array}{l}1.6(0-3.1) \\
0-6.1\end{array}$ & $\begin{array}{l}45.4(24.0- \\
53.2) \\
10.2-66.4\end{array}$ & $\begin{array}{l}53.3(40.6- \\
79.7) \\
18.1-97.2\end{array}$ & $\begin{array}{l}62.4(45.9- \\
85.1) \\
10.9-97.6\end{array}$ \\
\hline Blood loss quantitatively measured All Wales: $\mathrm{n}$ (\% of all episodes $\geq 1000 \mathrm{~mL}$ ) & $1204(83)$ & $1409(93)$ & $1404(93.7)$ & $1530(98.2)$ \\
\hline Percent blood loss measurement in individual units: Med (IQR) range & $\begin{array}{l}76.7(81.9- \\
90.2) \\
38-98\end{array}$ & $\begin{array}{l}93.6(88.6- \\
97.6) \\
86-100\end{array}$ & $\begin{array}{l}93.7(88.8- \\
98.5) \\
85-100\end{array}$ & $\begin{array}{l}99.1 \text { (98.3- } \\
99.6) \\
95-100\end{array}$ \\
\hline Rotem analysis performed: $\mathrm{n}$ (\% of episodes with bleeds $\geq 1500 \mathrm{~mL}$ ) & $206(37.7)$ & $346(58.8)$ & $380(71.7)$ & $371(68.2)^{b}$ \\
\hline Percent Rotem analyses performed in individual units: Med (IQR) range & $\begin{array}{l}24.9(16.2- \\
44.9) \\
10-88\end{array}$ & $\begin{array}{l}57.2(39.0- \\
74.4) \\
9-88\end{array}$ & $\begin{array}{l}59.2(67.5- \\
83.0) \\
39-100\end{array}$ & $\begin{array}{l}85.2(75.3- \\
90.6){ }^{b} \\
16-96\end{array}$ \\
\hline $\begin{array}{l}\text { Rotem analysis requiring intervention and acted on according to } \\
\text { algorithm: } \mathrm{n} \text { (\% of episodes with bleeds } \geq 1500 \mathrm{~mL} \text { ) }\end{array}$ & $3 / 16(19)$ & $18 / 35(51)$ & $19 / 29(65)$ & $25 / 37(68)^{b}$ \\
\hline
\end{tabular}
return Rotem data between July and December 2018. A more complete dataset was collected for PPH $\geq 1500 \mathrm{~mL}$ and so Rotem analyses and laboratory results are only reported for these cases 


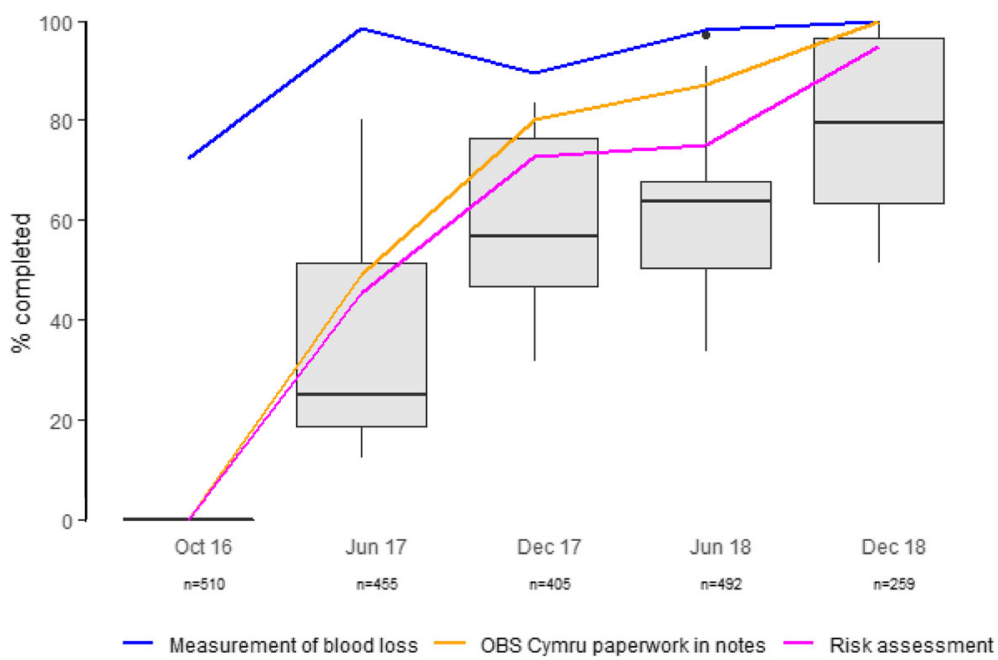

Fig. 1 Uptake of OBS Cymru interventions. Legend: The data indicate the percentage of cases where interventions were performed in consecutive women, irrespective of blood loss. Box plots with median, interquartile range and range refer to the combination of paperwork being present in the notes, the risk assessment having been completed and measured blood loss being performed

obstetric unit in the first and last 6 months of the project is shown in Fig. 3b and c. The number of obstetric units that transfused $\geq 50$ units of RBC per 1000 maternities fell from $8 / 12$ to $3 / 12(P=0.041)$. Despite the reduction in $\mathrm{RBC}$ transfusions, the proportion of women with a lowest $\mathrm{Hb}<80 \mathrm{~g} / \mathrm{L}$ did not increase (Table 3).

The proportion of women receiving FFP fell by $42 \%$ $(P=0.088)$ and the use of fibrinogen concentrate increased by $37 \%(P=0.26)$ between the first and last 6 months (Table 3). The decrease in FFP usage occurred mainly in the final 6 months after clinicians had been encouraged to correct fibrinogen before infusing FFP [26]. Infusion of cryoprecipitate and platelets was very uncommon (Table 3).

\section{Haemostatic impairment}

The number of laboratory coagulation tests reported increased over time and so differences between 6 month periods must be interpreted with caution. Despite this, the restrictive use of FFP was not associated with an increase in haemostatic impairment as demonstrated by the lowest fibrinogen and the longest PT/aPTT (Table 3). The median Fibtem A5 was $3 \mathrm{~mm}$ lower and more women had a Fibtem A $5<12 \mathrm{~mm}$ in the last 6 months, this is discrepant to the laboratory fibrinogen results and probably reflects the change in Fibtem A5 after the Rotem devices were updated. This may have affected the number of women receiving fibrinogen concentrate which increased in the last 6 months (Table 3).

\section{Maternal and staff feedback}

Results of the patient survey undertaken in 2017 have been reported [25]. Eight obstetric units collected 47 patient surveys in September 2018, mean (range) blood loss 1716 (1029-5743) mL (data was unavailable regarding the survey response rate). In total $66 \%$ of women

Table 2 PPH volume, admission to intensive care, hysterectomy and length of stay

\begin{tabular}{|c|c|c|c|c|}
\hline & Jan-Jun 2017 & Jul-Dec 2017 & Jan-Jun 2018 & Jul-Dec 2018 \\
\hline PPH $\geq 1000 \mathrm{~mL}: \mathrm{n}$ (/1000 maternities) & $1386(91.2)$ & $1480(92.6)$ & $1412(95.7)$ & $1490(98.3)$ \\
\hline PPH $\geq 1500 \mathrm{~mL}: \mathrm{n}$ (/1000 maternities) & $547(36.0)$ & $588(36.8)$ & $530(35.9)$ & $544(35.9)$ \\
\hline PPH $\geq 2000$ mL: n (/1000 maternities) & $228(15.0)$ & $232(14.5)$ & $228(15.5)$ & $209(13.8)$ \\
\hline PPH $\geq 2500 \mathrm{~mL}: \mathrm{n}$ (/1000 maternities) & $97(6.4)$ & $92(5.8)$ & $76(5.2)$ & $74(4.9)$ \\
\hline Admission to intensive care for PPH: $\mathrm{n}$ (/1000 maternities) & $10(0.66)$ & $12(0.75)$ & $9(0.61)$ & $6(0.40)$ \\
\hline Hours in intensive care for PPH: $\mathrm{n}$ (/1000 maternities) & $322.3(21.2)^{a}$ & $290(18.1)$ & $180(12.2)$ & $124(8.2)$ \\
\hline Hysterectomy associated with PPH: n (/1000 maternities) & $5(0.33)$ & $3(0.19)$ & $8(0.54)$ & $3(0.20)$ \\
\hline Length of hospital stay (days) for women with PPH $\geq 1500 \mathrm{~mL}$ : Med (IQR), range & $\begin{array}{l}2.09(1.37-3.27) \\
0.08-13.3\end{array}$ & $\begin{array}{l}2.01(1.29-3.22) \\
0.02-13.3\end{array}$ & $\begin{array}{l}2.12(1.45-3.23) \\
0.12-26.6\end{array}$ & $\begin{array}{l}2.11(1.44-3.20) \\
0.05-28.9\end{array}$ \\
\hline
\end{tabular}

Legend: The number of PPHs (/1000 maternities) between 1000 and $1499 \mathrm{~mL}$ was 55.2, 55.7, 59.8 and 62.4 in each six-month period. ${ }^{a}$ one woman spent $168 \mathrm{~h}$ on intensive care between January and June 2017 

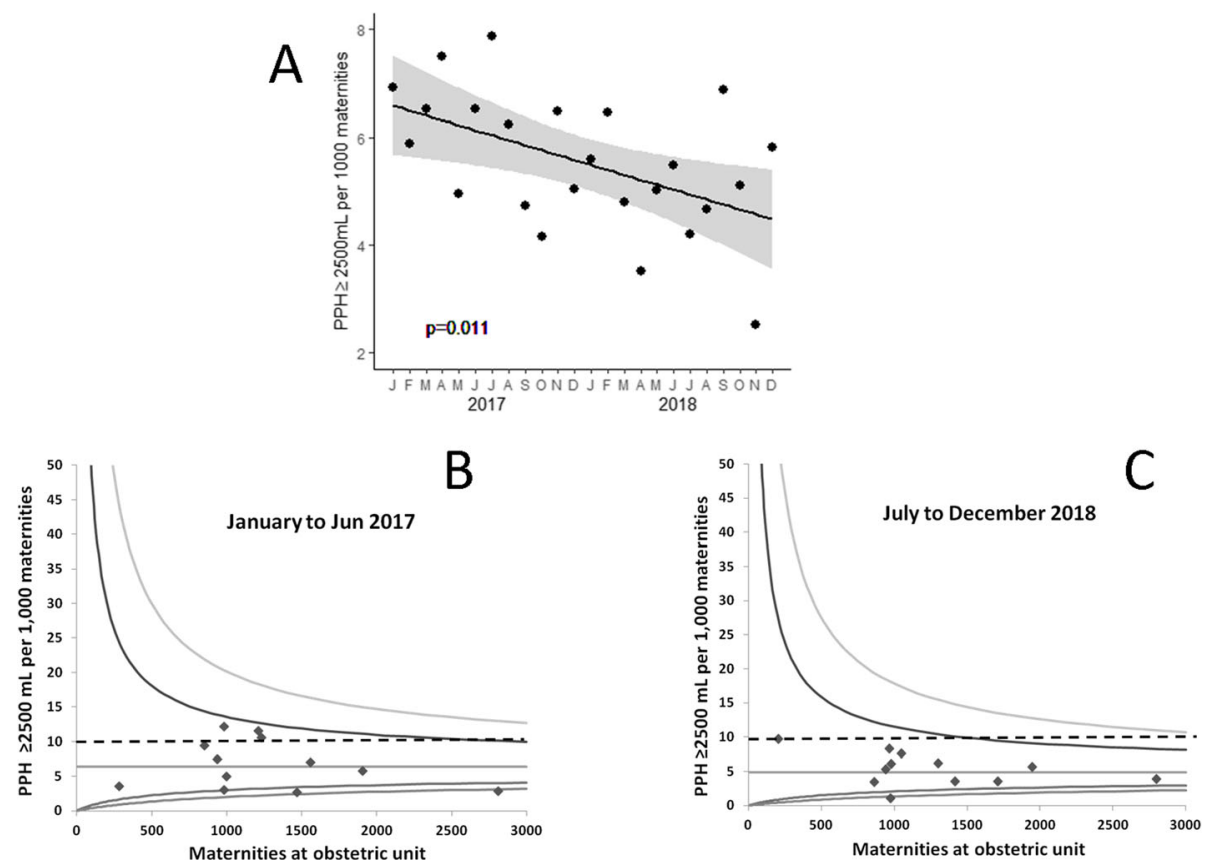

Fig. 2 Change in incidence of postpartum haemorrhage $\geq 2500 \mathrm{~mL}$ during OBS Cymru. Legend: Panel a shows the monthly rates for massive haemorrhage and the fitted regression line with $95 \%$ confidence interval shaded in grey. Funnel plots show the incidence of massive postpartum haemorrhages at each obstetric unit in the first (b) and last (c) 6 month periods of the quality improvement project. The line represents the mean and the limits shown are 2 and 3 standard deviations. The dashed line indicates a massive haemorrhage rate of 10/1000 maternities

remembered being told that they were having abnormal bleeding and although 95\% (39/41) felt well supported during the $\mathrm{PPH}, 29 \%(8 / 28)$ said that care could have been improved and better communication with mother and partner was suggested. No mother reported that the process of measuring blood loss or the escalating the multi-professional team response to her bleeding had a negative impact on the birth experience.

Local leadership staff survey, response rate 29/46 (63\%), reported that OBS Cymru had changed individual and unit level management of PPH. Table 4 shows the components of the intervention that clinicians thought had led to change.

\section{Discussion}

OBS Cymru was a national quality improvement project that aimed to reduce morbidity associated with PPH by introducing a care bundle into all 12 obstetric units in Wales. There were clinically and statistically significant reductions in massive haemorrhage across Wales with a $29 \%$ fall in the number of women progressing from moderate to massive PPH. The number of women exposed to RBC transfusion fell by $22 \%$ and the number of units of RBC transfused for PPH decreased by $26 \%$.

Adoption of the whole care bundle progressively improved throughout the project with quantitative blood loss measurement approaching 100\% during the last 6 months. This technique is more accurate than visual estimation, which tends to under-report actual volume, especially for large bleeds [32-37]. The increase in bleeds $\geq 1000 \mathrm{~mL}$ is likely to be a consequence of relative under-reporting during the early stages of OBS Cymru when quantitative measurement was being introduced. Similarly, recognition of massive haemorrhage is likely to have improved over time and so the reduction in the rate of PPHs $\geq 2500 \mathrm{~mL}$ may be an under-estimate.

The main strength of this report is that it represents service change implemented across an unselected realworld national cohort of women. It includes all women giving birth in Wales and all obstetric units irrespective of size, case mix and staffing levels. Women who gave birth in the community and experienced bleeding were transferred to an obstetric unit and are included in the results. The improvements in outcomes are internally consistent and continued throughout the project. The population, mode of delivery and cause of bleeding are similar to many high resource countries making the results widely applicable.

This report describes the changes observed over the course of the project and it cannot be known for certain that the improved outcomes were the result of the care bundle. However, improvements of the size observed are very unlikely to have happened simultaneously in multiple centres by chance and progressive improvement in 
Table 3 Transfusion and haematological results for postpartum haemorrhage

\begin{tabular}{|c|c|c|c|c|}
\hline & Jan-Jun 2017 & Jul-Dec 2017 & Jan-Jun 2018 & Jul-Dec 2018 \\
\hline \multicolumn{5}{|l|}{ Transfusion of red blood cells and blood components } \\
\hline $\begin{array}{l}\text { Number of women transfused red blood cells: } \mathrm{n} \text { (/1000 } \\
\text { maternities) }\end{array}$ & $350(23.0)$ & $270(16.9)$ & $278(18.8)$ & $268(17.7)$ \\
\hline $\begin{array}{l}\text { Total number of units of red blood cells transfused: } n \text { (/1000 } \\
\text { maternities) }\end{array}$ & $823(54.1)$ & $656(41.0)$ & $636(43.1)$ & $609(40.2)$ \\
\hline $\begin{array}{l}\text { Number of women transfused } \geq 5 \text { units red blood cells: } n \\
\text { (/1000 maternities) }\end{array}$ & $16(1.1)$ & $14(0.9)$ & $14(1.0)$ & $11(0.7)$ \\
\hline Number of women transfused FFP: $\mathrm{n}$ (/1000 maternities) & $26(1.7)$ & $20(1.3)$ & $21(1.4)$ & $15(1.0)$ \\
\hline Total number of units of FFP transfused: n (/1000 maternities) & $87(5.7)$ & $78(4.9)$ & $74(5.0)$ & $37(2.4)$ \\
\hline Number of women transfused fibrinogen: n (/1000 maternities) & $22(1.5)$ & $19(1.2)$ & $17(1.2)$ & $30(2.0)$ \\
\hline $\begin{array}{l}\text { Total number of grams of fibrinogen transfused: n (/1000 } \\
\text { maternities) }\end{array}$ & $94(6.2)$ & $103(6.4)$ & $89(6.0)$ & $137(9.0)$ \\
\hline $\begin{array}{l}\text { Number of women transfused cryoprecipitate: } n \text { (/1000 } \\
\text { maternities) }\end{array}$ & $6(0.4)$ & $3(0.2)$ & $2(0.1)$ & $5(0.3)$ \\
\hline $\begin{array}{l}\text { Total number of units of cryoprecipitate transfused: } n \text { (/1000 } \\
\text { maternities) }\end{array}$ & $14(0.9)$ & $8(0.5)$ & $4(0.3)$ & $9(0.6)$ \\
\hline Number of women transfused platelets: n (/1000 maternities) & $12(0.79)$ & $8(0.50)$ & $6(0.41)$ & $7(0.46)$ \\
\hline $\begin{array}{l}\text { Total number of units of platelets transfused: } \mathrm{n} \text { (/1000 } \\
\text { maternities) }\end{array}$ & $20(1.3)$ & $13(0.8)$ & $10(0.7)$ & $9(0.6)$ \\
\hline \multicolumn{5}{|l|}{ Haematological results } \\
\hline Lowest Clauss fibrinogen results: Med (IQR), range & $4.2(3.4-5), 0.3-9.2$ & $\begin{array}{l}4.1(3.4-4.8), 0.5- \\
8.1\end{array}$ & $4.2(3.5-4.7), 0.3-8$ & $\begin{array}{l}4.2(3.5-4.8), 0.3- \\
9.8\end{array}$ \\
\hline $\begin{array}{l}\text { Number with lowest fibrinogen } \leq 2 \mathrm{~g} / \mathrm{L} \mathrm{n} / \text { reported results (\% of } \\
\text { reported results) }\end{array}$ & $24 / 383(6.3)$ & 18/399 (4.5) & $17 / 435(3.9)$ & 22/459 (4.8) \\
\hline Longest PT results: Med (IQR), range & $\begin{array}{l}10.7(10.3-11.3) \\
9.2-22.4\end{array}$ & $\begin{array}{l}10.6(10.3-11.1) \\
9.1-80\end{array}$ & $\begin{array}{l}10.4(10.1-10.9) \\
8.3-18.4\end{array}$ & $\begin{array}{l}10.4(10-10.9), 9- \\
19.5\end{array}$ \\
\hline $\begin{array}{l}\text { Number with longest PT > } 16 \mathrm{~s} \mathrm{n} / \text { reported results (\% of } \\
\text { reported results) }\end{array}$ & $5 / 384(1.3)$ & $5 / 388(1.3)$ & $5 / 434(1.2)$ & $4 / 458(0.9)$ \\
\hline Longest aPTT results: Med (IQR), range & $\begin{array}{l}25.9(24.1-27.6) \\
20-84\end{array}$ & $\begin{array}{l}25.6(23.9-27.5) \\
19.5-143\end{array}$ & $\begin{array}{l}25.1(23.7-27.2) \\
19.3-105\end{array}$ & $\begin{array}{l}24.9(23.5-26.8) \\
18.7-42.5\end{array}$ \\
\hline $\begin{array}{l}\text { Number with longest aPPT > } 50 \mathrm{~s} \text { n/reported results (\% of } \\
\text { reported results) }\end{array}$ & $4 / 384(1.0)$ & $3 / 388(0.8)$ & $2 / 435(0.5)$ & $0 / 458(0.0)$ \\
\hline Lowest Fibtem A5 results: Med (IQR), range & $21(18-25), 4-49$ & $21(17-24), 2-63$ & $22(19-25), 2-55$ & $18(16-21), 0-60$ \\
\hline $\begin{array}{l}\text { Number with lowest Fibtem A5 }<12 \text { mm n/reported results (\% } \\
\text { of reported results) }\end{array}$ & $14 / 205(6.8)$ & 26/344 (7.6) & $23 / 378(6.1)$ & $30 / 369(8.1)$ \\
\hline Longest Extem CT results: Med (IQR), range & $57(52-62), 17-120$ & 57 (52-63), 38-147 & 56 (52-61), 30-300 & $55(51-61), 11-481$ \\
\hline $\begin{array}{l}\text { Number with longest Extem CT > } 75 \mathrm{~s} \mathrm{n} / \text { reported results (\% of } \\
\text { reported results) }\end{array}$ & $8 / 205(3.9)$ & $15 / 344(4.4)$ & $19 / 378(5.0)$ & $9 / 369(2.4)$ \\
\hline Lowest haemoglobin results: Med (IQR), range & $\begin{array}{l}91(71-100), 46- \\
135\end{array}$ & $\begin{array}{l}89(80-100), 54- \\
139\end{array}$ & 88 (78-98), 47-137 & $\begin{array}{l}88(79-100), 52- \\
137\end{array}$ \\
\hline $\begin{array}{l}\text { Number with lowest haemoglobin }<80 \mathrm{~g} / \mathrm{L} \text { n/reported results } \\
\text { (\% of reported results) }\end{array}$ & $55 / 203(27.1)$ & $99 / 327(30.3)$ & $82 / 353(23.2)$ & $55 / 306(18.0)$ \\
\hline
\end{tabular}

outcomes coincided with the progressive adoption of the intervention. The largest improvements in massive haemorrhage occurred in obstetric units with high initial rates possibly, in part, due to regression towards the mean.

The blood component algorithm emphasised early treatment of hypofibrinogenaemia in line with previous studies and guidelines $[5,6,12,15,18,20,38]$. In the last 6 month period the Rotem devices had a hardware update associated with a fall in median Fibtem.
Clinicians should be wary of variations between and within point-of-care devices and engage local laboratory expertise and monitor local normal ranges [19].

Quantitative measurement of blood loss alone does not improve outcomes [39]. However, when integrated into a care bundle such as OBS Cymru, real time accurate knowledge of blood loss acts as an enabler to prompt teams to escalate care according to guidelines [6, 38]. The changes in massive haemorrhage and concurrent 

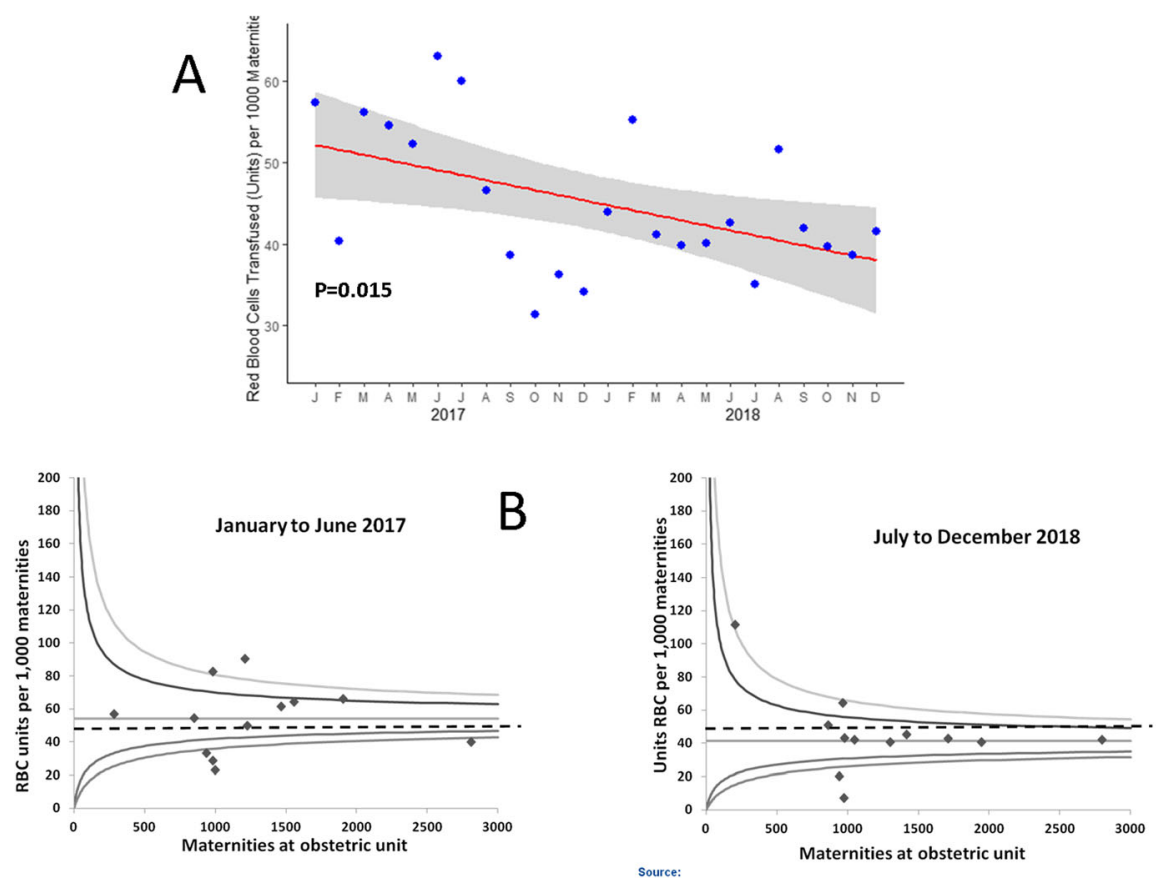

Fig. 3 Change in incidence of red blood cell transfusion during OBS Cymru. Legend: Panel a shows the monthly rates for red blood cell transfusion and the fitted regression line with 95\% confidence interval shaded in grey. Funnel plots show the incidence of RBC transfusion for postpartum haemorrhages at each obstetric unit in the first (b) and last (c) 6 month periods of the quality improvement project. The line represents the mean and the limits shown are 2 and 3 standard deviations. The dashed line represents a RBC transfusion rate of 50 units/1000 maternities

uptake of OBS Cymru interventions suggest that measuring blood loss and using Rotem, facilitated by multiprofessional team attendance at the bedside, were important factors. This was supported by feedback from clinicians, with blood loss measurement, team working and point-of-care coagulation tests stated to be the most influential changes to practice.

The rate of hysterectomy for $\mathrm{PPH}$ remained low throughout the project (0.31/1000 maternities). Consideration of early hysterectomy in cases of abnormal placentation is advocated by guidelines and $58 \%$ of hysterectomies were reported to have abnormal placental implantation [6, 7]. Other studies report a hysterectomy rate of $0.6-1 / 1000$ maternities [3, 21] demonstrating that hysterectomies were uncommon in Wales before OBS Cymru and this may explain why improvements were not seen.

The number of women transfused RBCs for PPH fell by $22 \%$, equivalent to about 160 women in Wales avoiding transfusion annually. RBC transfusion fell to 40 units/1000 maternities compared to a UK average of about 100 units/1000 maternities. Despite this, the lowest $\mathrm{Hb}$ during a PPH was similar throughout the 2 year period and the proportion of women with Hb below 80 $\mathrm{g} / \mathrm{L}$ did not increase, suggesting the reduction in transfusion reflected reduced bleeding rather than withholding RBCs inappropriately. Treatment of antenatal anaemia

Table 4 Contribution of intervention to practice change during OBS Cymru

\begin{tabular}{ll}
\hline Intervention & $\begin{array}{l}\text { Importance to practice change, } \boldsymbol{n}=\mathbf{2 9} \\
\text { (1- not important, 5- most important) } \\
\text { Median (IQR) }\end{array}$ \\
\hline Quantitative measurement of blood loss & $5(4-5)$ \\
Team working & $5(3-5)$ \\
Point-of-care testing of coagulation & $5(3-5)$ \\
Paperwork proforma & $4(1-4)$
\end{tabular}

Legend: Responses were $37.9 \%$ midwifery, $37.9 \%$ anaesthesia, $17.2 \%$ obstetrics, $6.9 \%$ haematology. Free text responses describing changes in individual practice included 'awareness of ongoing blood loss', 'proactive rather than reactive', 'consistent management', 'appropriate product administration', 'communication and team-working'. Barriers to implementation were reported by $69 \%$ (20/29) with the most common theme being training $(70 \%$, 14/20). This was also the leading response for overcoming barriers $53.5 \%(8 / 15)$ 
was consistent throughout the project supported by the finding that the first recorded $\mathrm{Hb}$ remained unchanged across the 2 year period.

RBCs, FFP and platelets are often transfused in fixedratios for major $\mathrm{PPH}[5,6,21,24,40-43]$ based on data derived from major trauma [44, 45] $\mathrm{PPH}$ differs from major trauma because at term women have an expanded circulating blood volume and are hypercoagulable [46, 47] and can maintain adequate haemostasis despite moderate blood loss $[15,16]$. Clinically significant deficiency of coagulation factors other than fibrinogen is uncommon in $\mathrm{PPH}$ and fixed-ratio transfusion algorithms may result in women receiving FFP with normal coagulation [17]. In OBS Cymru PT/aPTT > 1.5 times normal was seen in $1 \%$ of women experiencing a PPH $\geq 1500 \mathrm{~mL}$ whilst fibrinogen $<2 \mathrm{~g} / \mathrm{L}$ occurred in about $5 \%$, consistent with other studies $[13,15,16]$ In OBS Cymru Extem clot time was used to guide FFP infusion, with a $42 \%$ reduction in women receiving FFP. This occurred mainly in the last 6 months after the importance of correcting hypofibrinogenaemia before FFP administration was emphasised. During this time fewer women had PT/aPTT $>1.5$ times normal demonstrating that conservative use of FFP during $\mathrm{PPH}$, guided by point-of-care tests, does not increase haemostatic impairment [15].

Other large-scale quality improvement projects for $\mathrm{PPH}$ have combined risk assessment, measured blood loss, standardised escalation and empirical, as opposed to targeted, blood component resuscitation [21, 22, 24]. These initiatives have shown that, with high adoption of the interventions, severe morbidity can be reduced [21]. Sites adopting The California Maternal Quality Care Collaborative care bundle reported a $21 \%$ reduction in severe maternal morbidity [24]. The Association of Women's Health, Obstetric, and Neonatal Nurses PPH Project implemented a care bundle into 58 hospitals over 18 months. There was variable uptake and no statistically significant difference in maternal morbidity [22]. The lack of dedicated multiprofessional time was identified as a barrier. The use of multi-professional leadership teams in OBS Cymru, embedded at both a local and national level, with dedicated time to lead change, contributed to the speed, uptake and success of the project.

The integrated care bundle introduced universal risk assessment to identify mothers of increased risk of PPH, whilst quantitative measurement of blood loss enabled early recognition of abnormal bleeding and progression. This facilitated escalation to more experienced midwives and obstetricians to treat the underlying cause of bleeding earlier whilst anaesthetists focused on timely resuscitation. Point-of-care tests identified cases of hypofibrinogenaemia, allowing targeted and rapid correction of coagulopathy whilst avoiding inappropriate FFP in the majority. Early identification of normal coagulation facilitated escalation of obstetric measures to control bleeding.

\section{Conclusions}

A care bundle for the management of $\mathrm{PPH}$, that included point-of-care tests of coagulation to guide the treatment of coagulopathy, was introduced as a national quality improvement project involving more than 30,000 maternities annually. Clinically significant improvements in PPH outcomes, including rates of massive haemorrhage and $\mathrm{RBC}$ transfusion are achievable on a national level using quality improvement methodology. Obstetric units of all size and case mix implemented and benefitted from the care bundle with improved national outcomes. These results suggest that trends towards increasing incidence of severe $\mathrm{PPH}$ seen over recent years can be reversed by structured multi-professional team interventions. A cluster randomised trial is needed to investigate whether the OBS Cymru care bundle improves outcomes for PPH compared to standard care.

\section{Abbreviations}

PPH: Postpartum haemorrhage; RBC: red blood cells; FFP: fresh frozen plasma

\section{Supplementary Information}

The online version contains supplementary material available at https://doi. org/10.1186/s12884-021-03853-y

Additional file 1: Figure S1. Data collection proforma for postpartum haemorrhage of $1000 \mathrm{~mL}$ and $1500 \mathrm{~mL}$. Figure S2. Interrupted time series analysis of massive postpartum haemorrhage (>2500 mL) before and after OBS Cymru.

\section{Acknowledgements}

This quality improvement project would not have been possible without the support of the local teams whose hard work and enthusiasm is acknowledged.

Patient and public representatives on the OBS Cymru steering committee: Victoria Karis and Gill Boden.

Bronglais General Hospital, Aberystwyth: S Roberts, S Kumar, A Hamon, C Davies and S Nicholas.

Glangwili General Hospital, Carmarthen: S Roberts, R Evans, L Shankar and S Nicholas.

Nevill Hall Hospital, Abergavenny: E Mills, M Byrne, G Lilley, A Pinto, J Bruton, W Jones, S Lewis and S Beuchel.

Prince Charles Hospital, Merthyr Tydfil: J Shuck, S Morris, S Carlyon, D Bruynseels, V Sinha, N Swamy, J Rogers, M Ellis, W Bashi and S Reddivari. Princess of Wales Hospital, Bridgend: N Marong, D Nicolson, F Benjamin, R Jones, M Dey, C Morgan, R Jones and A Benton.

Royal Glamorgan Hospital, Llantrisant: K Godwin, L Clarke, N Tailor, H Davies, A Ahmed, J Pembridge, N Bhal, I Sabet and A Shokoohi.

Royal Gwent Hospital, Newport: E Mills, C Richards, S Parveen, M Silcocks, J Anderson and S Beuchel.

Singleton Hospital, Swansea: C Harris, S Williams, M Garry, N Jenkins, L Mukhopadhyay, D Apsee, H Saitch and A Benton.

University Hospital of Wales, Cardiff: D James, S Morris, A Albiet, G Stevens, C Salisbury, R Lye and R Hurton.

Ysbyty Glan Clwyd, Rhyl: I Watson, J Kelly, M Armstrong and S Evans. Ysbyty Gwynedd, Bangor: G Roberts, L Bolton, C Pritchard and S Evans. Ysbyty Maelor, Wrexham: B Green, J Young, L Verghese and L Desoysa. M Laing, School of Medicine, Cardiff University, helped with data analysis. 


\section{Authors' contributions}

SFB: designed OBS Cymru, obtained funding, led the quality improvement project, analysed data and co-wrote the first draft of the manuscript. REC: led the research under-pinning OBS Cymru, designed OBS Cymru, obtained funding, led the quality improvement project, analysed data and co-wrote the first draft of the manuscript. PP: analysed data and revised the manuscript. CB: designed OBS Cymru, managed the quality improvement project, collected data and revised the manuscript. $\mathrm{KJ}$ : designed OBS Cymru, managed the quality improvement project, collected data and revised the manuscript. MJ: designed OBS Cymru, managed the quality improvement project, collected data and revised the manuscript. KK: designed OBS Cymru, managed the quality improvement project, collected data and revised the manuscript. TK: designed OBS Cymru, managed the quality improvement project, collected data and revised the manuscript. CS: designed OBS Cymru, managed the quality improvement project, collected data and revised the manuscript. AW: designed and developed the OBS Cymru database, analysed data and revised the manuscript. TE: designed OBS Cymru, managed the quality improvement project, collected data and revised the manuscript. EM: designed OBS Cymru, managed the quality improvement project, collected data and revised the manuscript. KG: designed OBS Cymru, managed the quality improvement project, collected data and revised the manuscript. IV: designed OBS Cymru, managed the quality improvement project, collected data and revised the manuscript. JT: designed OBS Cymru, managed the quality improvement project, collected data and revised the manuscript. NS: managed the quality improvement project, collected data and revised the manuscript. IR: managed the quality improvement project, collected data and revised the manuscript. CF: designed OBS Cymru, managed the quality improvement project, collected data and revised the manuscript. PWC: led the research under-pinning OBS Cymru, managed the quality improvement project, analysed data and co-wrote the first draft of the manuscript. The author(s) read and approved the final manuscript.

\section{Funding}

OBS Cymru was funded by an Efficiency Through Technology grant from the Welsh Government. It was supported by Improvement Cymru (the national improvement body for NHS Wales) and the Welsh Deanery through Clinical Leadership Fellows.

Werfen loaned 10 Rotem Sigma devices to sites in Wales for the duration of the project and subsidised reagents required to perform assays. Werfen provided technical support, maintenance and annual service of all 12 Welsh devices, funded through the Welsh Government grant.

The funders played no role in the design of the study and collection, analysis, and interpretation of data and in writing the manuscript.

\section{Availability of data and materials}

The datasets generated and/or analysed during the current study are not publicly available because there are held on a quality improvement database hosted by Cardiff and Vale University Health Board. Anonymised data are available from the corresponding author on reasonable request.

\section{Declarations}

\section{Ethics approval and consent to participate}

The lead research and development office (Cardiff and Vale University Health Board) designated OBS Cymru as a quality improvement project and service evaluation according to NHS guidance. Consequently ethical approval and individual consent to collect and report data was not required.

\section{Consent for publication}

Not applicable.

\section{Competing interests}

RE Collis has received research support from CSL Behring, Werfen and Haemonetics.

PW Collins has received honoraria from CSL Behring and Werfen and research support from CSL Behring, Werfen and Haemonetics. He has received support to attend a conference from CSL Behring. All other authors have no conflicts of interest to declare.

\section{Author details}

'Department of Anaesthetics, Intensive Care and Pain Medicine, Cardiff and Vale University Health Board, Cardiff, UK. ${ }^{2}$ Deputy Director Research Design and Conduct Centre, Centre for Trials Research, College of Biomedical and Life Sciences, Cardiff University, Cardiff, UK. ${ }^{3}$ Department of Anaesthetics, Intensive Care and Pain Medicine, Betsi Cadwaladr University Health Board, Glan Clwyd Hospital, Bodelwyddan, UK. ${ }^{4}$ Department of Emergency Medicine, Aneurin Bevan University Health Board, Newport, UK. ${ }^{5}$ Department of Obstetrics and Gynaecology, Cardiff and Vale University Health Board, Cardiff, UK. ${ }^{6}$ Improvement Cymru, Public Health Wales, Cardiff, UK. ${ }^{7}$ Department of Midwifery, Singleton Hospital, Swansea, UK. ${ }^{8}$ Department of Obstetrics and Gynaecology, Cwm Taf Morgannwg Health Board, Merthyr Tydfil, UK. ${ }^{9}$ Department of Anaesthetics and Intensive Care, Aneurin Bevan University Health Board, Newport, UK. ${ }^{10}$ Department of Obstetrics and Gynaecology, Betsi Cadwaladr University Health Board, Glan Clwyd Hospital, Bodelwyddan, UK. ${ }^{11}$ Institute of Infection and Immunity, School of Medicine, Cardiff University, Cardiff, UK.

\section{Received: 20 September 2020 Accepted: 5 May 2021}

Published online: 15 May 2021

\section{References}

1. Say L, Chou D, Gemmill A, Tunçalp Ö, Moller AB, Daniels J, et al. Global causes of maternal death: a WHO systematic analysis. Lancet Glob Health. 2014;2(6):e323-e33. https://doi.org/10.1016/S2214-109X(14)70227-X.

2. Kramer MS, Berg C, Abenhaim H, et al. Incidence, risk factors, and temporal trends in severe postpartum hemorrhage. Am J Obstet Gynecol. 2013; 209(5):449 e1-7.

3. Lennox C, Marr L. Scottish confidential audit of severe maternal morbidity. 10th annual report (data from 2012). 2013. http://www.healthca reimprovementscotland.org/our_work/reproductive,_maternal_child/progra mme_resources/scasmm.aspx.

4. Bell SF, Watkins A, John M, Macgillivray E, Kitchen TL, James D, Scarr C, Bailey CM, Kelly KP, James K, Stevens JL, Edey T, Collis RE, Collins PW Incidence of postpartum haemorrhage defined by quantitative blood loss measurement: A national cohort. BMC Pregnancy Childbirth 2020;20(1). https://doi.org/10.1186/s12884-020-02971-3.

5. Collins P, Kadir R, Thachil J. Management of coagulopathy associated with postpartum haemorrhage: guidance from the SSC of ISTH. J Thromb Haemost. 2016;14(1):205-10. https://doi.org/10.1111/jth.13174.

6. Mavrides E, Allard S, Chandraharan $\mathrm{E}$, et al. Prevention and management of postpartum haemorrhage. Brit J Obstet Gynaecol. 2016;124(5):e106-e49. https://doi.org/10.1111/1471-0528.14178.

7. WHO guidelines for the management of postpartum haemorrhage and retained placenta. Geneva: World Health Organisation Press; 2009.

8. Sentilhes L, Gromez A, Clavier E, et al. Long-term psychological impact of severe postpartum hemorrhage. Acta Obstetricia et Gynecol Scand. 2011; 90(6):615-20 doi: Article.

9. Al Wattar BH, Tamblyn JA, Parry-Smith W, et al. Management of obstetric postpartum hemorrhage: A national service evaluation of current practice in the UK. Risk Manag Healthcare Policy. 2017;10:1-6 doi: Article.

10. Carroll F. Patterns of maternity care in English NHS Trusts 2018 [Available from: https://www.rcog.org.uk/globalassets/documents/guidelines/resea rch\%2D\%2Daudit/maternity-indicators-2013-14_report2.pdf. Accessed 12 May 2021.

11. Knight $M$, Bunch $K$, Tuffnell $D$, et al. Saving lives, improving mothers' care 2018 [Available from: https://www.npeu.ox.ac.uk/assets/downloads/mbrraceuk/reports/MBRRACE-UK\%20Maternal\%20Report\%202018\%20-\%20Web\%2 OVersion.pdf. Accessed 12 May 2012.

12. Charbit $B$, Mandelbrot $L$, Samain $E$, et al. The decrease of fibrinogen is an early predictor of the severity of postpartum hemorrhage. J Thromb Haemost. 2007;5(2):266-73. https://doi.org/10.1111/j.1538-7836.2007.02297.x.

13. Collins PW, Lilley G, Bruynseels D, Laurent DBS, Cannings-John R, Precious E, et al. Fibrin-based clot formation as an early and rapid biomarker for progression of postpartum hemorrhage: a prospective study. Blood. 2014; 124(11):1727-36. https://doi.org/10.1182/blood-2014-04-567891.

14. Jones R, Hamlyn V, Collis R, et al. Platelets count and transfusion requirements during moderate or severe postpartum haemorrhage. Anaesthesia. 2016;71(6):648-56. https://doi.org/10.1111/anae.13448.

15. Collins PW, Cannings-John R, Bruynseels D, Mallaiah S, Dick J, Elton C, et al. Viscoelastometry guided fresh frozen plasma infusion for postpartum 
haemorrhage: OBS2, an observational study. Br J Anaesth. 2017;119(3):42234. https://doi.org/10.1093/bja/aex245.

16. De Lloyd L, Bovington R, Kaye A, et al. Standard haemostatic tests following major obstetric haemorrhage. Int J Obstet Anesth. 2011;20(2):135-41. https://doi.org/10.1016/j.j.joa.2010.12.002.

17. Collins PW, Bell SF, Lloyd d, et al. Management of postpartum haemorrhage: from research into practice, a narrative review of the literature and the Cardiff experience. Int J Obstet Anesth. 2018;37:106-17.

18. Collins PW, Cannings-John R, Bruynseels D, Mallaiah S, Dick J, Elton C, et al. Viscoelastometric-guided early fibrinogen concentrate replacement during postpartum haemorrhage: OBS2, a double-blind randomized controlled trial. Br J Anaesth. 2017;119(3):411-21. https://doi.org/10.1093/bja/aex181.

19. Curry NS, Davenport R, Pavord S, Mallett SV, Kitchen D, Klein AA, et al. The use of viscoelastic haemostatic assays in the management of major bleeding: a British Society for Haematology guideline. Br J Haematol. 2018; 182(6):789-806. https://doi.org/10.1111/bjh.15524.

20. McNamara H, Kenyon C, Smith R, Mallaiah S, Barclay P. Four years' experience of a ROTEM ${ }^{-}$-guided algorithm for treatment of coagulopathy in obstetric haemorrhage. Anaesthesia. 2019;74(8):984-91. https://doi.org/1 $0.1111 /$ anae. 14628 .

21. Shields LE, Wiesner S, Fulton J, Pelletreau B. Comprehensive maternal hemorrhage protocols reduce the use of blood products and improve patient safety. Am J Obstet Gynecol. 2015;212(3):272-80. https://doi.org/10.1 016/j.ajog.2014.07.012.

22. Bingham D, Scheich B, Bateman BT. Structure, process, and outcome data of AWHONN's postpartum hemorrhage quality improvement project. JOGNN. 2018:47(5):707-18. https://doi.org/10.1016/j.jogn.2018.05.002.

23. Shields LE, Smalarz K, Reffigee $L$, et al. Comprehensive maternal hemorrhage protocols improve patient safety and reduce utilization of blood products. Am J Obstet Gynecol 2011;205(4):368-68.

24. Main EK, Cape V, Abreo A, et al. Reduction of severe maternal morbidity from hemorrhage using a state perinatal quality collaborative. Am J Obstet Gynecol. 2017;216(3):298.e1-98.e11. https://doi.org/10.1016/j.ajog.2017.01.017.

25. Bell SF, Kitchen T, Miriam J, et al. Designing and Implementing an All Wales Postpartum Haemorrhage Quality Improvement Project: OBS Cymru (The Obstetric Bleeding Strategy for Wales). BMJ Quality. 2020;9:e000854.

26. Obstetric Anaesthetist Association. OBS Cymru checklist and Rotem protocol 2019 [Available from: https://www.oaa-anaes.ac.uk/ui/content/content.a spx?ID=76. Accessed 12 May 2021.

27. Powell $E$, James $D$, Collis $R$, et al. Introduction of standardised, cumulative quantitative measurement of blood loss into routine maternity care. J Maternal-Fetal Neonatal Med. 2020. https://doi.org/10.1080/14767058.2020.1 759534

28. Shakur H, Roberts I, Fawole B, Chaudhri R, el-Sheikh M, Akintan A, et al. Effect of early tranexamic acid administration on mortality, hysterectomy, and other morbidities in women with post-partum haemorrhage (WOMAN): an international, randomised, double-blind, placebo-controlled trial. Lancet. 2017;389(10084):2105-16. https://doi.org/10.1016/S0140-6736(17)30638-4.

29. Maternity Network Wales. Prevention and management of postpartum haemorrhage 2017 [Available from: http://www.wisdom.wales.nhs.uk/ sitesplus/documents/1183/All\%20Wales\%20Prevention\%20of\%20Postpa rtum\%20Haemorrhage\%20\%281.4\%29_2018.pdf. Accessed 12 May 2021.

30. Hiippala ST, Myllyla GJ, Vahtera EM. Hemostatic factors and replacement of major blood loss with plasma-poor red cell concentrates. Anesth Analg. 1995;81(2):360-5. https://doi.org/10.1097/00000539-199508000-00026.

31. Maternity Network Wales. PROMPT Wales strategy 2018 [Available from: http://www.nwssp.wales.nhs.uk/sitesplus/documents/1178/PROMPT\%20Wa les\%20Strategy\%20V1-3.pdf. Accessed 12 May 2021.

32. Duthie SJ, Ven D, Yung GLK, et al. Discrepancy between laboratory determination and visual estimation of blood loss during normal delivery. Eur J Obstet Gynecol Reprod Biol. 1991;38(2):119-24 doi: Article.

33. Stafford I, Dildy GA, Clark SL, et al. Visually estimated and calculated blood loss in vaginal and cesarean delivery. Am J Obstet Gynecol. 2008;199(5):519. e1-19.e7. https://doi.org/10.1016/j.ajog.2008.04.049.

34. Bose P, Regan F, Paterson-Brown S. Improving the accuracy of estimated blood loss at obstetric haemorrhage using clinical reconstructions. BJOG. 2006;113(8):919-24. https://doi.org/10.1111/j.1471-0528.2006.01018.x

35. Kahr M, Brun R, Zimmermann R, et al. Validation of a quantitative system for real.Time measurement of postpartum blood loss. Arch Gynecol Obstet. 2018;298(6):1071-7. https://doi.org/10.1007/s00404-018-4896-0.
36. Lilley G, Burkitt St Laurent D, Precious E, et al. Measurement of blood loss during postpartum haemorrhage. Int J Obstet Anesth. 2015;24(1):8-14 https://doi.org/10.1016/j.ijoa.2014.07.009.

37. Patel A, Goudar SS, Geller SE, Kodkany BS, Edlavitch SA, Wagh K, et al. Drape estimation vs. visual assessment for estimating postpartum hemorrhage. Int J Gynecol Obstet. 2006;93(3):220-4. https://doi.org/10.1016/ji.jgo.2006.02.014.

38. WHO. WHO recommendations for the prevention and treatment of postpartum haemorrhage 2012 [Available from: https//www.who.int/reproductivehealth/publica tions/maternal_perinatal_health/9789241548502/en/. Accessed 12 May 2021.

39. Hancock A, Weeks AD, Lavender DT. Is accurate and reliable blood loss estimation the 'crucial step' in early detection of postpartum haemorrhage: an integrative review of the literature. BMC Pregnancy Childbirth. 2015;15(1): 230-9. https://doi.org/10.1186/s12884-015-0653-6.

40. Pacheco LD, Saade GR, Costantine MM, Clark SL, Hankins GD. The role of massive transfusion protocols in obstetrics. Am J Perinatol. 2013:30(1):1-4. https://doi.org/10.1055/s-0032-1322511.

41. Pavord S, Maybury H. How I treat postpartum hemorrhage. Blood. 2015; 125(18):2759-70. https://doi.org/10.1182/blood-2014-10-512608.

42. Saule I, Hawkins N. Transfusion practice in major obstetric haemorrhage: lessons from trauma. Int J Obstet Anesth. 2012;21(1):79-83. https://doi.org/1 0.1016/j.joa.2011.09.009.

43. Tanaka H, Matsunaga S, Yamashita T, Okutomi T, Sakurai A, Sekizawa A, et al, A systematic review of massive transfusion protocol in obstetrics. Taiwan J Obstet Gynecol. 2017;56(6):715-8. https://doi.org/10.1016/.j.jog.2017.10.001.

44. Zink KA, Sambasivan CN, Holcomb JB, Chisholm G, Schreiber MA. A high ratio of plasma and platelets to packed red blood cells in the first 6 hours of massive transfusion improves outcomes in a large multicenter study. Am J Surg. 2009;197(5):565-70. https://doi.org/10.1016/j.amjsurg.2008.12.014.

45. Davenport R, Brohi K. Causes of trauma-induced coagulopathy. Curr Opinions Anesthesiol. 2016;29(2):212-9. https://doi.org/10.1097/ACO 0000000000000295

46. Allard S, Green L, Hunt BJ. How we manage the haematological aspects of major obstetric haemorrhage. Br J Haematol. 2014;164(2):177-88. https://doi. org/10.1111/bjh.12605.

47. Collis R, Collins P. Haemostatic management of obstetric haemorrhage. Anaesthesia. 2015;70(Supple 1):78-86.

\section{Publisher's Note}

Springer Nature remains neutral with regard to jurisdictional claims in published maps and institutional affiliations.

Ready to submit your research? Choose BMC and benefit from

- fast, convenient online submission

- thorough peer review by experienced researchers in your field

- rapid publication on acceptance

- support for research data, including large and complex data types

- gold Open Access which fosters wider collaboration and increased citations

- maximum visibility for your research: over $100 \mathrm{M}$ website views per year

At $\mathrm{BMC}$, research is always in progress.

Learn more biomedcentral.com/submissions 